Nebojša Janićijević1*, Katarina Ignjatović Paunović

${ }^{1}$ University of Belgrade, Faculty of Economics, Serbia ${ }^{2}$ Porta de lux, d.o.o., Serbia

\title{
Employee and the Self-Employed Job Satisfaction: Similarities and Differences
}

DOI: 10.7595/management.fon.2018.0024

\begin{abstract}
:
Research question: This paper investigates if there are differences between employees and the self-employed job satisfaction levels. Motivation: The motive for this research was the desire to determine the validity of the assumption that the self-employed are more satisfied with their jobs than employees, and also to investigate for the first time in Serbia the differences in the self-employed and employee job satisfaction. The paper relies on earlier research works that have all shown that the self-employed are more satisfied with their jobs than employees (Blanchflower, 2004). This is due to the autonomy at work that the self-employed have, while employees experience it in a smaller degree. In addition, the selfemployed also have better opportunities to organize their work so that it can be interesting,a greater flexibility at work and larger income. Idea: In this perspective, the central hypothesis of this study is that in Serbia, and also other researched countries, the self-employed job satisfaction is higher than that of the employees in their firms. Therefore, the research has been directed to determine whether job satisfaction, as a dependent variable, is systematically different depending on the respondents' status (self-employed - employee), as an independent variable. Data: The research included 127 employees in 15 different business firms run by the self-employed from different parts of Serbia. Of the total number of respondents, 52 were self-employed while 75 were employees. The respondents rated the importance of and their satisfaction with 12 job dimensions. Tools: While calculating the average importance and satisfaction rates of the self-employed and employees, as well as the statistical significance of the differences in their ratings by means of independent sample t test, significant results have been obtained. Findings: Just like in the earlier research, it has been confirmed that the self-employed show a higher level of total job satisfaction in comparison with employees. Statistically significant differences in the job dimensions' importance exist only in the job dimension "Work that does not require overtime", which is significantly more important to employees than to the self-employed. With respect to job satisfaction, statistically significant differences exist in 6 out of 12 job dimensions, and in each of them the self-employed are more satisfied than the employees. Unlike in earlier research, the main source of the self-employed satisfaction is not autonomy at work, but personal responsibility in task completion, safe working conditions and friendly atmosphere at work. Contribution: The study has once again shown that the selfemployed are more satisfied with their job in comparison with the employees, and that this also applies in Serbia.
\end{abstract}

Key Words: job satisfaction, self-employment, small firm, job dimensions, autonomy at work, Serbia

JEL: M10, M12

\section{Introduction}

Job satisfaction is one of the most researched topics in the organizational behaviour and human resource management field (Fila, Paik, Griffeth, \& Allen, 2014; Haesevoets, Folmer, De Cremer, \& Van Hiel, 2013; Heneman \& Judge, 2000). The reason for this is certainly the assumption that a satisfied worker is also a productive worker, and that enhancing employees' satisfaction also enhances the company performance (Judge, Thoresen, Bono, \& Patton, 2001; Wong, Hiu, \& Law, 1998; Staw, 1986). Although it may sound reasonable, this assumption has not been empirically proven mostly due to the complexity of both job satisfaction and productivity (Kovacevic \& Petrovic, 2006; Vandenheuvel \& Wooden, 1997). Nevertheless, it is still the main source of interest in the job satisfaction topic. 
Job satisfaction is the attitude that an employee has towards his/her work and it can be defined as "individual's cognitive, affective, and evaluative reactions towards his or her job" (Locke, 1969, pp312). Job satisfaction is a complex attitude because it involves an employee's reaction towards different job aspects or dimensions, such as: job per se, salary, working conditions, relationships with managers and colleagues, etc. (Janicijevic, Kovacevic \& Petrovic, 2015; Filiz, 2014; Nandan \& Krishna, 2013; Kinicki, Schriesheim, McKee-Ryan \& Carson, 2002). According to Locke $(1976,1969)$, job satisfaction is present to the extent to which people are satisfied with the outcome of the job itself. In addition, it is very important not only how much employees receive from their job, but also whether they get what they want and appreciate. The more an individual receives the outcome he/she values, the more satisfied the individual will be (Kovacevic \& Petrovic, 2006). Thus, in order to predict someone's job satisfaction, one must consider not only the satisfaction with different aspects of the individual's job, but also his/her expectations from the job.

Although job satisfaction is a highly researched field, the self-employed job satisfaction has to a far smaller extent been the focus of researchers (Binder \& Coad, 2013; Blanchflower, 2004) and in Serbia there was no such research at all. The self-employed are the owners of firms who at the same time perform some job in their firms (Jamal, 1997). The self-employed are very important for any country's economy, and this is especially true for Serbia, since this is one of the ways of dealing with high unemployment rate. Job satisfaction is often marked as one of the motives for self-employment (Yu \& Su, 2014). If this is true, it means that the self-employed job satisfaction is one of the factors of decreasing the country's unemployment rate level. There is a reasonable assumption, lergely empirically proven in the world (Blanchflower, 2004), that the self-employed are more satisfied with their jobs than the employees. Higher autonomy at work, higher personal responsibility in task completion, an opportunity to select challenging and interesting work, a potentially higher salary and flexible working hours are just some of the reasons why a self-employed person is more satisfied with his/her job than an employee.

This research has three objectives: First, to once again investigate if the self-employed are indeed more satisfied than their employees as the past research suggests. The second objective is to identify job dimensions that the self-employed are more/less satisfied with than their employees. The third objective is to investigate, for the first time in Serbia, whether there are any differences in job satisfaction between the self-employed and employees. The research was conducted by surveying 127 self-employed and employees, whereby they rated importance and satisfaction with different job dimensions.

The paper is structured as follows. First, the literature review on the self-employed job satisfaction will be presented, the research methodology will be described, and the research results will be presented. Next, the results will be discussed in order to present the conclusion of the research.

\section{Literature Review}

Blanchflower is the most cited author when analyzing the relationship between self-employment and job satisfaction. The results of his research (Blanchflower, 2004) confirmed that the self-employed showed higher job satisfaction in comparison with all other employees in the US as well as in the majority of the European countries. His research also showed that, in comparison with all other employees, the self-employed in Europe were also more satisfied with the salary, type of work they do, but that they were less satisfied with the working hours.

Benz and Frey $(2008,2003)$ proved that the self-employed are significantly more satisfied with their jobs than the employees. In order to prove their hypotheses, they used the data obtained from the International Social Survey Program in 1997, conducted in 23 countries of Western Europe, North America, and Eastern Europe and which included 16,000 respondents. Higher self-employed job satisfaction was confirmed in all countries except New Zealand. Also, the research has shown that higher autonomy at work is the job aspect which is the main cause of higher self-employed job satisfaction in all groups of countries. In addition, it has been proven that the self-employed consider their job as more interesting than employees do.

In his research, Hundley (2001) proved that the self-employed feel a higher job satisfaction than employees in organizations as well as that the self-employed have a slightly higher job satisfaction than higher-level employees (managers) and employees of certain professions (physicians, dentists, veterinarians, lawyers, architects, geodesists, and civil engineers) who enjoy greater autonomy and use of skills at work. The two main causes of higher job satisfaction of the self-employed are greater autonomy in tasks completion and larger task diversity. 
Parasumaran and Simmers (2001) have shown that self-employed persons enjoy greater autonomy and schedule flexibility at work, and report higher levels of job involvement and job satisfaction than those employed in organizations, but that they also experience higher levels of work-family conflict and lower family satisfaction than organizational employees.

Prottas and Thompson (2006) have also concluded that self-employed people feel higher satisfaction due to a higher degree of autonomy at work, but they have also shown that this also applies to independent contractors as a type of the self-employed people.

Millan, Hessels, Thurik, and Aguado (2013) have shown that the self-employed are more satisfied with the type of work, but less satisfied with job security. The results further show that the self-employed who have employees feel higher job satisfaction than those who do not have employees. By using the data from the 2006 European Social Survey (ESS), Lange (2012) has confirmed the existence of a higher degree of job satisfaction among the self-employed in comparison with other employees. Further data analysis led him to conclude that higher job satisfaction of the self-employed was the consequence of their greater autonomy and independence at work. Several more authors, and among them Arum and Müller (2004), Bradley and Roberts's (2004), Vandenheuvel and Wooden (1997) and Hanglberger and Merz (2015), have confirmed in their studies that the self-employed are more satisfied with their job than the employees.

The summary of the research in the mentioned studies shows that job satisfaction is higher in the selfemployed than in the employees. Research also shows that autonomy at work is one of the main reasons why the self-employed are more satisfied with their jobs.

\section{Research Methodology}

The research into job satisfaction of the self-employed and employees included a total of 127 respondents from 15 firms. Of the total number of respondents, 52 are self-employed - the owners of small firms who, besides managerial and owner's duties, also perform certain work in their firms. The other 75 respondents are employees in the firms owned by the first group of respondents. The average number of employees in the firms included in the research is 10 . Over a quarter of the included firms are family businesses, that is, the co-owners are spouses or other family members (parents, siblings). The sample is highly heterogeneous with respect to the industries in which the included firms operate and includes the following businesses: PVCu and aluminium doors and windows manufacturing firms, internal and external safety doors manufacturing firms, restaurants, bookkeeping agencies, beauty parlours, grocery shops, private kindergartens, speech therapy centres, office supplies trading companies, bakeries, fast-food firms, secondary materials trade companies, foreign language learning schools. The sample contains $55.9 \%$ women and $44.1 \%$ men. Most respondents are married (59.1\%) while $30 \%$ of them are single. The rest are divorced or living with an unmarried partner. The majority of respondents belong in the group with 6 to 10 years of service within the firm, the group with 2 to 5 years of service within the firm contains $29.1 \%$ respondents, while the group with up to 2 years of service within the firm contains $16.5 \%$ respondents. The largest number of respondents have a high-school education (41.7\%), followed by $29.9 \%$ with university education, while $15.7 \%$ of respondents have a two-year college diploma.

The research was conducted in the period April-July 2017 in the firms located in Belgrade, Novi Sad, Kragujevac and Novi Pazar. As we can see, besides Belgrade, the sample covers large cities in Vojvodina, and in Central and Southern Serbia. The company selection was based on availability criterion - we have selected firms whose owners agreed to be included into the research. The respondents completed an online electronic questionnaire by means of Google Docs service.

The research instrument was developed for this study following the model of questionnaires used in some previous studies of job satisfaction (Janicijevic et al., 2015; Petrovic, Kovacevic \& Kutlesic, 2007; Kovacevic \& Petrovic, 2006; Kinicki, et al., 2002; Judge \& Welbourne, 1993). The main feature of the questionnaire used in this study is that the respondents first rated the importance and then the satisfaction with different job dimensions on a 1 to 5 scale. The rated job dimensions were selected from the job satisfaction scales used in previous research mentioned in this study (Janicijevic et al., 2015; Millan, et al., 2013; Lange, 2012; Benz \& Frey, 2008). The selection criterion was relevance for small businesses, start up companies and family businesses. The second part of the instrument refers to the respondents' general data: sex, age, marital status, employment status, years of service within the firm, education level, and salary. The instrument was highly reliable, both for the importance and satisfaction assessments. Cronbach's alpha coefficient was 0.961 for the importance assessments, and 0.968 for the satisfaction assessments. 
The following statistical methods were applied in the research: arithmetic mean and standard deviation for expectations and different job dimensions satisfaction, as well as Independent Samples t-Test used to determine statistical significance of the differences in the self-employed and employees' answers.

\section{The Research Results}

The aim of the research is to determine if there are differences in job satisfaction level between the selfemployed and the employees. Also, the goal is to determine which job dimensions show statistically significant differences with respect to satisfaction of the self-employed and the employees. Table 1 presents the results of testing statistical significance of the differences between the self-employed and employees in general job satisfaction.

Table 1: Differences between the self-employed and employees in general job satisfaction

\begin{tabular}{|l|l|l|l|l|l|l|}
\hline & Respondents & $\begin{array}{l}\text { No. of } \\
\text { respondents }\end{array}$ & $\begin{array}{l}\text { Arithmetic } \\
\text { mean }\end{array}$ & $\begin{array}{l}\text { Standard } \\
\text { deviation }\end{array}$ & t-statistic & Significance \\
\hline $\begin{array}{l}\text { General job } \\
\text { satisfaction }\end{array}$ & Self-employed & 52 & 4.17 & 0.834 & 2.392 & $0.018^{\star}$ \\
\cline { 2 - 5 } & Employees & 75 & 3.81 & 0.833 & \\
\hline \multicolumn{7}{|c|}{$\begin{array}{l}\text { Source: Author's calculation } \\
\text { Significance level: } 0.05\end{array}$} \\
\hline
\end{tabular}

Based on the results presented in Table 1, it could be observed that there is a statistically significant difference between the two respondent groups in evaluation of general job satisfaction, evidenced by the tstatistic (2.392), which is statistically significant at the level of $0.05(p<0.05)$. The validity of the hypothesis that the self-employed total job satisfaction is higher than the employees' total job satisfaction is proven. The average score for the self-employed is 4.17 , while the average score for employees is 3.81 .

According to Locke's theory $(1976,1969)$, satisfaction with individual job dimensions is not the product of satisfaction alone, but also of the importance that the different dimensions have for the self-employed and employees. Therefore, the job expectations of the self-employed and of the employees and whether there are significant differences between the two groups will be presented first.

Table 2: Differences between the self-employed and the employees in evaluation of the importance of job dimensions

\begin{tabular}{|c|c|c|c|c|c|}
\hline Job dimensions & Respondents & $\begin{array}{l}\text { Arithmetic } \\
\text { mean }\end{array}$ & $\begin{array}{l}\text { Standard } \\
\text { deviation }\end{array}$ & t-statistic & Significance \\
\hline \multirow{2}{*}{ Job Security } & Self-employed & 4.50 & .918 & \multirow{2}{*}{-0.129} & \multirow{2}{*}{0.897} \\
\hline & Employees & 4.52 & .811 & & \\
\hline \multirow{2}{*}{ Amount of salary } & Self-employed & 4.33 & .785 & \multirow{2}{*}{-1.542} & \multirow{2}{*}{0.126} \\
\hline & Employees & 4.52 & .623 & & \\
\hline \multirow{2}{*}{ Colleague support } & Self-employed & 4.44 & .698 & \multirow{2}{*}{1.177} & \multirow{2}{*}{0.241} \\
\hline & Employees & 4.27 & .905 & & \\
\hline \multirow[b]{2}{*}{$\begin{array}{l}\text { Personal responsibility in } \\
\text { task completion }\end{array}$} & Self-employed & 4.65 & .556 & \multirow[b]{2}{*}{1.258} & \multirow[b]{2}{*}{0.211} \\
\hline & $\begin{array}{l}\text { Employees Job } \\
\text { security }\end{array}$ & 4.49 & .795 & & \\
\hline \multirow{2}{*}{$\begin{array}{l}\text { Possibilities for professional } \\
\text { development }\end{array}$} & Self-employed & 4.38 & .718 & \multirow{2}{*}{-0.209} & \multirow{2}{*}{0.835} \\
\hline & Employees & 4.41 & .790 & & \\
\hline \multirow{2}{*}{$\begin{array}{l}\text { Challenging and interesting } \\
\text { job }\end{array}$} & Self-employed & 4.40 & .721 & \multirow{2}{*}{1.279} & \multirow{2}{*}{0.203} \\
\hline & Employees & 4.23 & .798 & & \\
\hline \multirow{2}{*}{ Friendly atmosphere } & Self-employed & 4.65 & .623 & \multirow{2}{*}{1.441} & \multirow{2}{*}{0.152} \\
\hline & Employees & 4.45 & .859 & & \\
\hline \multirow{2}{*}{$\begin{array}{l}\text { Company's public image and } \\
\text { reputation }\end{array}$} & Self-employed & 3.94 & .998 & \multirow{2}{*}{0.861} & \multirow{2}{*}{0.391} \\
\hline & Employees & 3.77 & 1.146 & & \\
\hline \multirow{2}{*}{$\begin{array}{l}\text { Work that does not require } \\
\text { overtime }\end{array}$} & Self-employed & 3.27 & 1.223 & \multirow{2}{*}{-2.092} & \multirow{2}{*}{$0.038^{*}$} \\
\hline & Employees & 3.73 & 1.234 & & \\
\hline \multirow{2}{*}{ Safe working conditions } & Self-employed & 4.56 & .698 & \multirow{2}{*}{0.763} & \multirow{2}{*}{0.447} \\
\hline & Employees & 4.44 & .948 & & \\
\hline \multirow{2}{*}{$\begin{array}{l}\text { Absence of tension and } \\
\text { pressure at work }\end{array}$} & Self-employed & 4.60 & .664 & \multirow{2}{*}{1.526} & \multirow{2}{*}{0.129} \\
\hline & Employees & 4.39 & .820 & & \\
\hline \multirow{2}{*}{ Autonomy at work } & Self-employed & 3.94 & 1.037 & & \\
\hline & Employees & 3.72 & .966 & 1.237 & 0.218 \\
\hline
\end{tabular}


The results show that the self-employed in the sample consider personal responsibility in task completion to be the most important job dimension. Friendly atmosphere and the related absence of tension and pressure at work immediately follow. The least important job dimensions for the self-employed are work that does not require overtime, company's public image and reputation, and autonomy at work. For the employees from the sample, the most important job aspect is job security, followed by the amount of salary and personal responsibility in task completion. Employees have the least expectations from autonomy at work, work that does not require overtime, and company's public image and reputation. With respect to differences between the self-employed and employees regarding the importance of different job dimensions, the research has found statistically significant differences in only one dimension: work that does not require overtime. Although this is a job dimension whose importance is relatively undervalued by both the selfemployed and employees, it can still be observed that absence of overtime work is still far less important to the self-employed than to the employees.

Next, we will analyze the levels of satisfaction with individual job dimensions of the self-employed and the employees and also if there are any differences in that respect.

Table 3: Differences between the self-employed and employees in satisfaction with different job dimensions

\begin{tabular}{|c|c|c|c|c|c|}
\hline Job dimensions & Respondents & $\begin{array}{l}\text { Arithmetic } \\
\text { mean }\end{array}$ & $\begin{array}{l}\text { Standard } \\
\text { deviation }\end{array}$ & t-statistic & Significance \\
\hline \multirow[t]{2}{*}{ Job security } & Self-employed & 4.17 & 1.004 & \multirow[t]{2}{*}{1.609} & \multirow[t]{2}{*}{0.110} \\
\hline & Employees & 3.88 & 1.013 & & \\
\hline \multirow[t]{2}{*}{ Amount of salary } & Self-employed & 4.06 & .916 & \multirow[t]{2}{*}{3.099} & \multirow[t]{2}{*}{$0.002^{\star}$} \\
\hline & Employees & 3.52 & .991 & & \\
\hline \multirow[t]{2}{*}{ Colleague support } & Self-employed & 4.23 & .942 & \multirow[t]{2}{*}{2.229} & \multirow[t]{2}{*}{$0.028^{*}$} \\
\hline & Employees & 3.81 & 1.099 & & \\
\hline \multirow{2}{*}{$\begin{array}{l}\text { Personal responsibility in task } \\
\text { completion }\end{array}$} & Self-employed & 4.44 & .639 & \multirow[t]{2}{*}{1.892} & \multirow[t]{2}{*}{0.061} \\
\hline & Employees & 4.17 & .876 & & \\
\hline \multirow{2}{*}{$\begin{array}{l}\text { Possibilities for professional } \\
\text { development }\end{array}$} & Self-employed & 3.96 & .862 & \multirow[t]{2}{*}{3.847} & \multirow[t]{2}{*}{$0.000^{\star}$} \\
\hline & Employees & 3.25 & 1.116 & & \\
\hline \multirow[t]{2}{*}{ Challenging and interesting job } & Self-employed & 4.12 & .839 & \multirow[t]{2}{*}{2.830} & \multirow[t]{2}{*}{$0.005^{\star}$} \\
\hline & Employees & 3.60 & 1.115 & & \\
\hline \multirow[t]{2}{*}{ Friendly atmosphere } & Self-employed & 4.46 & .699 & \multirow[t]{2}{*}{3.359} & \multirow[t]{2}{*}{$0.001^{*}$} \\
\hline & Employees & 3.80 & 1.294 & & \\
\hline \multirow{2}{*}{$\begin{array}{l}\text { Company's public image and } \\
\text { reputation }\end{array}$} & Self-employed & 4.21 & .776 & \multirow[t]{2}{*}{2.166} & \multirow[t]{2}{*}{$0.032^{\star}$} \\
\hline & Employees & 3.87 & .949 & & \\
\hline \multirow{2}{*}{$\begin{array}{l}\text { Work that does not require } \\
\text { overtime }\end{array}$} & Self-employed & 3.56 & .998 & \multirow[t]{2}{*}{-0.639} & \multirow[t]{2}{*}{0.524} \\
\hline & Employees & 3.69 & 1.284 & & \\
\hline \multirow[t]{2}{*}{ Safe working conditions } & Self-employed & 4.58 & .750 & \multirow[t]{2}{*}{1.778} & \multirow[t]{2}{*}{0.078} \\
\hline & Employees & 4.31 & .900 & & \\
\hline \multirow{2}{*}{$\begin{array}{l}\text { Absence of tension and } \\
\text { pressure at work }\end{array}$} & Self-employed & 3.90 & 1.192 & \multirow[t]{2}{*}{1.849} & \multirow[t]{2}{*}{0.067} \\
\hline & Employees & 3.49 & 1.256 & & \\
\hline \multirow[t]{2}{*}{ Autonomy at work } & Self-employed & 4.27 & .843 & 3.525 & $0.001^{*}$ \\
\hline & Employees & 3.65 & 1.046 & & \\
\hline
\end{tabular}

The results of the research have shown that the self-employed are most satisfied with the dimensions of safe working conditions, friendly atmosphere at work, and personal responsibility in job completion; while they are least satisfied with the aspects of work that does not require overtime, absence of tension and pressure at work, and an opportunity for professional development and growth. On the other hand, employees are most satisfied with the aspects of safe working conditions, personal responsibility in task completion, and employment security, while they are least satisfied with the aspects of opportunity for professional development and growth, absence of tension and pressure at work, and the amount of salary.

When the differences in the level of satisfaction with individual job dimensions between the self-employed and employees are analysed, the results show that, statistically significant in comparison with employees, the self-employed are more satisfied with the aspects of autonomy at work, challenging and interesting job, amount of salary, colleague support, friendly atmosphere, company's pubic image and reputation, and opportunities for professional development and growth. On the other hand, there is not a single job dimension in which employees are more satisfied than the self-employed that is statistically significant. 


\section{Discussion}

The research objective has been to determine whether there are differences in the levels of job satisfaction between the self-employed and the employees, as it was determined in previous research. The survey results have shown that there is a statistically significant difference in the total job satisfaction level between the selfemployed and the employees, specifically to the advantage of the self-employed. This was expected, having in mind that the same result was obtained in almost all world countries where similar research was conducted (Blanchflower, 2004; Benz \& Frey, 2008, 2003; Hundley, 2001; Millan, Hessels, Thurik, \& Aguado, 2013). This research has shown that being "one's own boss", regardless of all the great self-sacrifices it implies, makes one much more satisfied with the job than being employed in someone else's firm. With respect to differences in satisfaction with individual job dimensions, the results show that a statistically significant difference in job satisfaction level has been observed in as many as 6 job dimensions and that the self-employed are in all cases more satisfied with their jobs than the employees. On the other hand, no job dimensions were found in which the employees were more satisfied than the firm owners. The self-employed are more satisfied with the aspects of autonomy at work, challenging and interesting jobs, amount of salary, colleague support, friendly atmosphere, company's pubic image and reputation, and opportunities for professional development and growth.

The owners of firms have incomparably higher level of autonomy at work than any of the employees, regardless of how important this fact is to them. A large majority of previous studies have shown (Benz \& Frey, 2008, 2003; Hundley, 2001; Prottas \& Thompson, 2006; Parasumaran \& Simmers, 2001) that the selfemployed have higher autonomy at work than the employees do, which this study also confirms. Thus it is completely understandable why the self-employed are more satisfied with this job aspect than the employees, although neither group puts a particular emphasis on this aspect. Higher job satisfaction of the self-employed in comparison with that of the employees with the aspect of challenging and interesting job is, also, not surprising. The very fact that they have chosen to start a firm in a specific industry mostly points to the conclusion that they find that type of work interesting. Also, the owner having a choice with respect to which tasks he/she will perform in the firm contributes to this as well. The reason for higher satisfaction of the self-employed in comparison to employees with the aspect of the amount of salary is quite obvious. Higher satisfaction of the self-employed in the aspects of colleague support and friendly atmosphere at work could be explained by the nature of the relationships between firm owners and their employees. Since the employees depend on the owner, they avoid conflicting with the owner as they would conflict with their colleagues if there were any disagreements between them. In addition, the conflicts between employees are most often kept hidden from the owner, so the owner therefore inaccurately perceives the atmosphere in his/her firm. Finally, this result may also be explained by the finding of Berglund, Sevä \& Strandh (2016) that the self-employed, unlike the employees, show a positive correlation between 'agreeableness' and 'conscientiousness' as personal traits, on the one hand, and job satisfaction, on the other. The company's public image and reputation is the job dimension in which the owners of firms work much harder than the employees, so good results in this field bring them more satisfaction than they bring to the employees. From a statistically significant point of view, the self-employed are also more satisfied with the aspect of opportunity for professional development and growth. It is still clear that the firm owners have somewhat greater possibilities and space for professional development than their employees do.

In further text we will discuss the research results concerning the importance of and satisfaction with different job dimensions separately for the self-employed and the employees. Personal responsibility in task completion is the most important job dimension for the self-employed, which is not surprising. It is certain that the self-employed are precisely the kind of people who find personal responsibility in task completion very important and that this was maybe the reason for starting their own businesses.

It is interesting that for the self-employed in our research, unlike the self-employed in previous research (Lange, 2012; Prottas \& Thompson; 2006; Parasumaran \& Simmers, 2001), autonomy at work is not one of the most important job dimensions. The research results show that the self-employed evaluate the autonomy aspect as second-to-last out of 12 aspects. This unusual result requires some clarification. The research was conducted in small firms with 10 employees on average. For the firms with few employees to operate well, it is necessary that, besides the owner, the employees also participate in decision-making, and the entire firm should actually function as one team. Even though owners do have the possibility to independently make decisions about what, how much, when and how the firm will do business, they are aware that in order to be successful they must consider the opinions of other employees. Having in mind that the self-employed rated the job aspects of friendly atmosphere and absence of tension and pressure at work as the second and third in importance, respectively, it is clear that the above stated could explain why they rated the aspect of autonomy at work as they did. Another possible explanation for the low rating of importance of autonomy at work by the self-employed is high collectivism in Serbian national culture (Hofstede, 2002). In collectivistic cultures, autonomy is generally less valued than in individualist cultures. 
The most important job dimensions to the employees, with the same rating, are employment security and the amount of salary. Favouring these job aspects could be explained by the impact of unfavourable economic situation in the country, in particular, more by the duration of such situation rather than by its mere existence.

Both employees and the self-employed are most satisfied with the job aspects of safe working conditions and personal responsibility in task completion. A high degree of satisfaction with the aspect of safe working conditions, especially having in mind that it occurs in both groups of respondents, leads to the conclusion that in small firms included in the sample, much attention is dedicated to safety at work. This could, to some extent, be explained by the fact that the owners themselves also work in the same working conditions as their employees, so they certainly strive to provide good working conditions for themselves. The research results have shown that the aspect of personal responsibility in task completion is one of the three job aspects that both groups are most satisfied with, which is very significant and good, since it is also the aspect that both groups of respondents consider as one of the three most important ones as well. While something similar is to be expected from the self-employed, since, as the owners of the firms, they are certainly personally responsible for their business, this result is somewhat surprising for the employees. The explanation for such a high level of satisfaction in personal responsibility in task completion lies in the nature of organization of the small firms included in the sample. Specifically, due to a small number of employees in small organizations, it is impossible to reach a high specialization level as it is the case in large companies. The employees in small companies most often perform a task as a whole, rather than just one or several simple work operations, so it is only natural that they feel personally responsible to perform the task well.

Both groups of respondents are least satisfied with the job aspects of opportunity for professional development and growth and absence of tension and pressure at work. Dissatisfaction with opportunities for professional development and growth could be explained, for both the owners and their employees, by the fact that small firms in Serbia, including the ones from the sample, most often desperately fight to survive in the market, so they simply have neither time nor resources for the owners' and even less for the employees' professional development.

Since it occurs in both the owners and the employees, dissatisfaction with the aspect of absence of tension and pressure at work is the proof that working in small firms in Serbia is stressful. This result also confirms the previous evidence that in the self-employed there is a negative relation between being exposed to excessive stress and work-life balance satisfaction (Annink, Dulk \& Amoros, 2016). Small firms often do not have enough employees, because hiring new employees would bring the risk to the firm of not being profitable any more if it does not increase the business volume. For this reason, overloading of the existing employees with work, accepting several jobs at the same time, missing deadlines, and frequent project errors are very common problems, which brings stress into the work environment.

\section{Conclusions and limitations of the research}

All earlier research indicates that the self-employed show higher level of job satisfaction in comparison with the employees (Millan et al., 2013; Benz\&Frey, 2008; Blanchflower, 2004). The objective of this research has been to once again investigate if this is so and, especially, if this also applies to Serbia. Therefore, we have surveyed 127 self-employed and employees in 15 small businesses from different parts of Serbia. The respondents rated 12 job dimensions, as well as their satisfaction with these dimensions. The results have shown that the self-employed enjoy a higher level of total job satisfaction than the employees do, which complies with the results of the research conducted so far. Also, when observed by job dimensions, statistically significant differences in levels of satisfaction between the self-employed and the employees exist in 6 out of 12 job dimensions. In all of these job dimensions, the self-employed feel higher job satisfaction than the employees.

This research has had significant limitations which, to some extent, reduce its reliability and possibilities for the generalization of its results. The limitations primarily relate to research methodology. Above all, due to the manner of selection of the firms and respondents, the sample is representative by neither its size nor its structure; therefore, we cannot claim that the conclusions reached in the research apply generally to the entire Serbia. Secondly, the used questionnaire was especially designed for the purpose of this research, so its validity and reliability could not have been entirely proved. Finally, the ratings of the importance of and satisfaction with individual aspects of job satisfaction by the self-employed and the employees have not been controlled based on the impact of independent variables, such as gender, age, education, and especially the amount of salary. Therefore, it would be useful to repeat this research in future by using a larger and a more representative sample, with a reliable and already used questionnaire, and also by controlling of the impact of different independent variables that could modify the differences in job satisfaction between the self-employed and employees. 


\section{REFERENCES}

[1] Annink, A., Dulk, L., \& Amoros, J.E. (2016). Different strokes for different folks? The impact of heterogeneity in work characteristics and country contexts on work-life balance among the selfemployed, 22(6), 880-902. doi:10.1108/IJEBR-04-2016-0127

[2] Arum, R., \& Müller, W. (2004). The Reemergence of Self-Employment: Comparative Findings and Empirical Propositions. In R. Arum, W. Muler (Eds.), The Reemergence of Self-Employment: A Comparative Study of Self-Employment Dynamics and Social Inequality (pp. 426-454). Princeton, NJ: Prinston University Press.

[3] Blanchflower, D.G., (2004). Self-employment: More may not be better. Working paper 10286. Cambridge: National Bureau of economic research.

[4] Benz, M., \& Frey, B.S. (2008). Being independent is a great thing: subjective evaluations of selfemployment and hierarchy. Economica, 75(298), 362-383.

[5] Benz, M., \& Frey, B.S. (2003). The Value of autonomy: Evidence from the self-employed in 23 countries. Working Paper No. 173. Zurich: Institute for empirical research in economics University of Zurich.[6] Berglund, V., Sevä I.J., \& Strandh, M. (2016) Subjective well-being and job satisfaction among selfemployed and regular employees: does personality matter differently? Journal of Small Business \& Entrepreneurship, 28 (1), 55-73. doi.org/10.1080/08276331.2015.1115699

[7] Binder, M., \& Coad, A. (2013). Life satisfaction and self-employment: a matching approach, Small Business Economics, Vol. 40, No. 4 pp. 1009-1033

[8] Bradley, D.E., \& Roberts, J.A. (2004). Self-Employment and job satisfaction: Investigating the role of selfefficacy, depression, and seniority. Journal of Small Business Management, 42(1), 37-58.

[9] Fila, M., Paik, L., Griffeth, R., \& Allen, D. (2014) Disaggregating Job Satisfaction: Effects of Perceived Demands, Control, and Support Journal of Business and Psychology Vol. 29, No. 4, pp. 639-649

[10] Filiz, Z. (2014) An Analysis of the Levels of Job Satisfaction and Life Satisfaction of the Academic Staff, Social Indicators Research Vol. 116, No. 3, pp. 793-808

[11] Haesevoets, T., Folmer, R.C., De Cremer, D., \& Van Hiel, A. (2013). Money Isn't All That Matters: The Use of Financial Compensation and Apologies to Preserve Relationships in the Aftermath of Distributive Harm. Journal of Economic Psychology, 35, pp.95-107. .

[12] Hanglberger, D., \& Merz, J. (2015). Does self-employment really raise job satisfaction? Adaptation and anticipation effects on self-employment and general job changes. Working paper 2015 - 385. Luneburg: Society for the Study of Economic Inequality.

[13] Heneman, H.G., \& Judge, T.A. (2000). Compensation attitudes: A review and recommendations for future research. In S. L. Rynes and B. Gerhart (Eds.), Compensation in Organizations: Progress and Prospects (pp.61-103). San Francisco: Jossey-Bass.

[14] Hofstede, G. (2002). Images of Europe: Past, present and future. In M.Warner and P.Joynt (eds). Managing across cultures, (pp 89 - 103). London: Thomson.

[15] Hundley, G. (2001). Why and when are the self-employed more satisfied with their work? Industrial Relations, 40(2), 293-316.

[16] Jamal, M. (1997). Job stress, satisfaction, and mental health: An empirical examination of self-employed and non-self-employed Canadians. Journal of Small Business Management, 35 (4), 48-57.

[17] Janicijevic, N., Kovacevic, P. \& Petrovic, I. (2015). Identifying organizational factors of job satisfaction: The case of one Serbian company. Economic Annals, LX (205), 73-104. doi:10.2298/EKA1505073J

[18] Judge, T.A., Thoresen, C.J., Bono, J.E., \& Patton, G.K. (2001). The job satisfaction - job performance relationship: A qualitative and quantitative review. Psychological Bulletin, 127 (3), 376-407

[19] Judge, T.A., \& Welbourne, T.M. (1993). Dimensionality of the Pay Satisfaction Questionnaire: A Confirmatory Factor Analytic Investigation (CAHRS Working Paper \#93-09). Ithaca, NY: Cornell University, School of Industrial and Labor Relations, Center for Advanced Human Resource Studies. Retrieved from http://digitalcommons.ilr.cornell.edu/cahrswp/264

[20] Kinicki, A.J., Schriesheim, C.A., McKee-Ryan, F.M., \& Carson K.P. (2002). Assessing construct validity of the job descriptive index: Review and meta analysis. Journal of Applied Psychology, 87 (1), 14-32.

[21] Kovacevic, P. \& Petrovic, I. (2006). Managers' job satisfaction: Construct validation. In B. Cerovic, (Ed.), Privatisation in Serbia: Evidence and Analyses (pp.287-304). Beograd: Centar za izdavacku delatnost Ekonomskog fakulteta

[22] Lange, T. (2012). Job satisfaction and self-employment: Autonomy or personality? Small Business Economics, 38, (2), 165-177. doi.org/10.1007/s11187-009-9249-8

[23] Locke, E.A. (1976). The Nature and Cause of Job Satisfaction. In M.D.Dunette (Ed). Handbook of Industrial and Organizational Psychology. Chicago: Rand McNally.

[24] Locke, E.A. (1969). What is job satisfaction? Organizational Behavior and Human Performance, 4(4), 309-336. 
[25] Millan, J.M., Hessels, J., Thurik, R., \& Aguado, R. (2013). Determinants of job satisfaction: a European comparison of self-employed and paid employees. Small Business Economics, 40 (3), 651-670. doi.org/10.1007/s11187-011-9380-1

[26] Nandan, R. \& K. Krishna, S.R., (2013) Determinants of Job Satisfaction of Faculty in Higher Education Indian Journal of Industrial Relations, Vol. 49, No. 1 pp. 132-147

[27] , S. \& , C.A. (2001), Type of employment, work-family conflict and well-being: a comparative study, Journal of Organiaztional Behavior, 22 (5), 551-568. DOI: 10.1002/job.102.

[28] Prottas, D. J., \& Thompson, C. A. (2006). Stress, satisfaction, and the work-family interface: A comparison of self-employed business owners, independents, and organizational employees. Journal of Occupational Health Psychology, 11(4), 366-378. doi.org/10.1037/1076-8998.11.4.366

[29] Petrovic, I., Kovacevic, P., \& Kutlesic, V. (2007). Correlates of General Managers' Job Satisfaction Within a Transition Economy, APA (American Psychological Association) 115th Annual Convention, San Francisco, California.

[30] Staw B. (1986). Organizational psychology and the pursuit of the happy/productive worker. California Management Review, 28(4), 40-53.

[31] Vandenheuvel, A., \& Wooden, A. (1997). "Self-Employed Contractors and Job Satisfaction, Journal of Small Business Management, 35(3), 11-20.

[32] Wong, C.S, Hiu, C., \& Law, K., (1998) A Longitudinal Study of the Job Perceptions and Job Satisfaction Relationship: A Test of Three Alternative Specifications, Journal of Occupational and Organizational Psychology, 71(2), pp.127-146. DOI: 10.1111/j.2044-8325.1998.tb00667.x

[33] Yu, W., \& Su, K. (2014) On One's Own: Self-Employment Activity in Taiwan. In R. Arum, W. Muler, (Eds.), The Reemergence of Self-Employment: A Comparative Study of Self-Employment Dynamics and Social Inequality, (pp. 388-426). Princeton, NJ: Prinston University Press.

Received: 2018-04-21

Revisions requested: 2018-06-13

Revised: 2018-09-03

Accepted: 2018-09-11

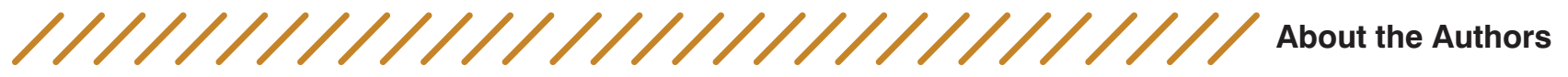

Nebojša Janićijević
University of Belgrade, Faculty of Economics
jnebojsa@eunet.rs

Nebojša Janićijević is a full professor at the Faculty of Economics, University of Belgrade, where he teaches courses in the field of organization, human resources management, and change management to students at undergraduate, graduate and doctoral studies. He has authored and co-authored several books, and a number of articles in foreign and domestic academic journals, and has participated in many international scientific conferences. He has been at three study stays at the U.S. universities as a receiver of Fulbright Program fellowships. Nebojša Janićijević is a consultant for leading domestic companies in the filed of organizational restructuring and human resource management.

\section{Katarina Ignjatović Paunović} Porta de lux d.o.o.

Katarina Ignjatović Paunović is the co-owner of the Porta de lux d.o.o. firm, which she manages since 2007. She earned her Bachelor's Degree in Journalism and Communication from the Faculty of Political Sciences, University of Belgrade, in 2007, and her Master's Degree in Business Management from the Faculty of Economics, University of Belgrade, in 2017. Katarina's field of interest refers to researching job satisfaction in employees in small companies, as well as marketing and management

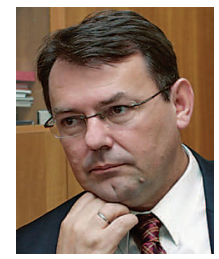
focused on the consumers. 